\title{
Traktát o vybraných problémech teorie a praxe v oblasti pedagogických věd
}

\author{
Jaroslav Kot’a \\ Katedra pedagogiky, Filozofická fakulta, Univerzita Karlova
}

Redakci zasláno 17. 5. 2012 / upravená verze obdržena 3. 8. 2012 / k uveřejnění přijato 6. 8. 2012

Anotace: Traktát připomíná vztahy teorie a praxe v antice a v novověku, poukazuje na fetišizaci praxe v moderní době. Připomíná proměnu filosofování a upozorňuje na nástup vědotechniky, která ovládla současný společenský provoz. Otázka vztahu teorie a praxe $\mathrm{v}$ pedagogice je probrána $\mathrm{z}$ řady aspektů, zdůrazněny jsou rozdíly v akcentech významu teorie a praxe, je připomenut problém cvičných škol, mikroučení, hospitací, vlastních vystoupení studentů a vybrané aspekty vztahu k mimovyučovacím aktivitám, které by budoucí učitel měl umět zužitkovat.

Klíčová slova: epistémé, filosofie, fronésis, hospitace, marxismus, moudrost, mikroučení, teorie, praxe, přítomnost, techné, vědotechnika

Nejen filosofie, ale i vědy o člověku koncentrují mnohé aktivity kolem tvorby či redefinování klíčových pojmů, vyjadřujících podstatu toho, oč tyto disciplíny usilují. Samotné pojmy bez významových kontextů nemají valný obsah; ožívají nejen tehdy, když jsou uvedeny do filosofických či odborně vědních souvislostí, ale především v momentě, kdy se stanou součástí kladení problémových otázek. Také pojmy jako člověk, teorie či praxe získávají své významy v souvislostech, s nimiž se stávají součástí dobového horizontu, v němž si lidé vykládají problematičnost svého vlastního bytí.

Vztah teorie a praxe měl rozvinutou předehru již v antice u Aristotela, ale novou tematizaci získal v průběhu 19. století, kdy ideový vývoj spěl k završení vývoje německé klasické filosofie a posléze k tzv. antropologickému obratu v mladohegelovské levici. Ve dvacátém století v zemích, které skloňovaly jméno K. Marxe ve všech pádech, byla praxe $v$ nediferencované podobě vzývána jako prostředek na řešení všech možných potíží a současně poslední arbitr pravdivosti poznání; a to přesto, že právě v těchto zemích se projevovala výrazná filosofická sterilita a neschopnost tvůrčím způsobem dospět k novým poznatkům či konceptům - a dostat se nad východiska položená v historickém či v dialektickém materialismu, jak je jejich apologeti 
pojmenovali. ${ }^{1}$ Přitom jak v marxismu, tak v pozitivismu existovala výrazná tendence ke scientismu, tedy ke zbožnění vědy, od níž si marxisté i pozitivisté slibovali ráznou destrukci a nahrazení metafyzické filosofie vědeckým př́stupem ke světu.

Dalšími výrazy, které je vhodné připomenout, jsou současnost či prrítomnost. Ty neoznačují žádné přesné časové určení, ale mají ve filosofii zcela specifický smysl, nebot’ obsahují jednotu myšlení a tázání v určité historické situaci. A pro tuto situaci je jako typická vždy vybrána množina problémů charakterizujících ducha doby a vytvářejících svébytné ladění, v němž je tematizován problém bytí, člověka, poznání, jazyka filosofie či vědy apod. Bylo by neprozřetelné pojmout přítomné jako aktuální, protože to by znamenalo nechat spadnout pod pracovní stůl filosofa tzv. „věčné“ metafyzické problémy. Jejich existence však naopak může sugerovat, že to, co není uchopeno sub specie aeternitatis, má pouhou jepičí povahu a je odsouzeno k zítřejšímu zapomenutí. Lze snadno doložit, že $\mathrm{v}$ dějinách filosofie jde o to, aby tematizované problémy filosofie (jejichž podoby jsou uloženy v souboru vědění předloženém k diskusi všem na jevišti světa vystupujícím laickým i profesionálním filosofům) neznamenaly jakousi okamžitou pohotovost k řešení aktuálních situací, ale spíše umožnily odhalovat závažnost úkolů, které se v historických situacích staví před lidstvo $\mathrm{v}$ řadě nových a proměnlivých podob.

\section{Vědotechnika - součást osudu západního lidstva}

Položíme-li si otázku, co vyznačuje ražbu ducha současně žité epochy, zdá se, že namísto několika ústředních témat nalezneme řadu výrazně odlišných perspektiv. To je jedna z odzbrojujících charakteristik soudobého filosofování, i když nejde o nic nového, ani překvapujícího. V dějinách filosofie se vícekrát objevily ostré ideové střety včetně slavného „zápasu gigantů o podstatu jsoucna“ odehrávajícího se již na půdě antické filosofie. Nové je spíše to, že v průběhu posledních dvou století se rozevřel celý vějír filosofických směrů, které transformovaly $\mathrm{v}$ politické rovině v zápas světových názorů.

Některé podněty z marxismu se tvůrčím způsobem podařilo rozvést ve Frankurtské škole, jejíž činnost však byla záhy přerušena nástupem nacismu a posléze byla ostře odsuzována i ortodoxními marxisty. U nás se pokusy tvůrčím způsobem posunout marxistický odkaz pokusila řada myslitelů propojujících fenomenologii s marxismem, což bylo po r. 1968 odsouzeno, podobně jako mezi libri prohibity byla zařazena jediná originální marxistická studie z pera Karla Kosíka (1965) Dialektika konkrétního (studie o problematice člověka a světa). 
Tato konverze filosofických idejí a snaha vytvářet z nich orientující formy představování $\mathrm{v}$ podobě světových názorů diskreditují filosofování v očích široké veřejnosti, kterou zneklidňuje průnik ideologických aspektů do odborného myšlení.

V dějinách lze lehce nalézt epochy, kdy vůdčí úlohu v životní orientaci zaujímala teologie, dnes se ujímají vůdcovství vědy postupně se vydělující z corpusu filosofie a emancipující se v samostatné disciplíny. Soudobné vědy nejsou pěstovány jako čistá teorie či nazírání na svět, ale ruku v ruce s jejich ideovými výboji jsou vytvářeny aplikace jejích idejí v podobě technických či praktických řešení problémů. Proto filosofové užívají pro soudobé dědictví filosofie výraz vědotechnika, který podtrhuje výraznou alianci teoretického vědění $\mathrm{s}$ technickými aplikacemi. Pejorativní aspekt u tohoto pojmu naznačuje, že technizace vědy překročila hranice odbornosti a vnucuje řešení řady problémů i tam, kde by bylo vhodnější se vrátit k filosofii či k jiné podobě životní moudrosti.

Termín vědotechnika vyjadřuje jednu z nejvýraznějších verzí přeměny klasické teoretické distance vůči světu v nový typ vědění, který každodenní provoz poměřuje kriteriem užitečnosti. Situace zašla již tak daleko, že věda bez možnosti technických aplikací se zdá být zbytečným plýtváním času a energií. Takový luxus současná společnost nehodlá podporovat žádnými většími investičními prostředky; neužitečné podoby učenectví jsou ponechány pouze soukromníkům jako vhodná náplň jejich volného času.

Vědotechnika se do značné míry stala univerzálním nástrojem regulace nejen ideového pohybu ve vědách, ale ovlivňuje i snahy direktivně, leč podle nepředvídatelně měněných pravidel, regulovat samotnou vědu, čehož se s historicky nevídanou silou zmocňují nejrůznější grantové či akreditační komise jmenované vládami západních společností. Účelem takto reglementované vědy je sloužit aktuálním potřebám společnosti, podpořit praktické výstupy proti planému teoretizování, které je přípustné jen v podobě školské průpravy na vita activa ve vědotechnickém světě. Průvodní jevy tohoto přístupu zahalují svým stínem i celý provoz humanitních vysokých škol, které v epoše vlády volné sou těže jsou donucovány nevídaným způsobem plánovat vše, co se ještě z tradice nazývá výukou - od předem schválených studijních plánů pomalu se měnících $\mathrm{v}$ dogma, od dopředu zveřejňovaných sylabů, až po primitivní studijní opory pro ty, kteří již neumějí přečíst a excerpovat celá filosofická či vědecká díla, a až po populistická nadbíhání 
vkusu adeptů vědotechniky a současných hodnotitelů vzdělavatelského úsilí učitelů, mezi nimiž jsou aktivní paradoxně i ti, kteří absolvovali jednu či dvě přednášky za semestr a evidentně nejsou schopni vůbec porozumět kontextům a souvislostem odborných výkladů.

Nejnebezpečnějším dopadem vědotechnického přístupu ke světu nejsou jen soudobé excesy degradující provoz vysokých škol na jakési vyšší střední vzdělávací zařízení, i když rozklad vzdělanosti se nakonec vymstí celé společnosti. Problémem je to, že si lidé osvojují a berou za samozřejmou tendenci nahlížet na svět, na druhé lidi a na sebe sama technicky, tedy v podobě algoritmů a postupů, $\mathrm{v}$ nichž jsou záhady a tajemství transformovány $\mathrm{v}$ problémy, tedy v to, co je možné si stavět či před-mítat před oči jako předmět a co je řešitelné v technické podobě.

Jedním z průvodních jevů chodu civilizace ve vědotechnickém věku je respekt $\mathrm{k}$ zákonům, vyhláškám a dokumentům, jejichž diskurs je velmi často dílem anonymní masy úředníků operujících v různých komisích ad hoc či laických zákonodárců - a jejich slovník nahrazuje tradiční filosofické a vědecké termíny, nebo je v horším případě používá v deformované podobě. Rodí se nový typ homo instituta et ordinationes, tedy člověk institucí a předpisů, který úřední dokument považuje za nejvyšší možnou dosažitelnou moudrost, za níž už nelze jít dál ani o její hloubce pochybovat. $V$ tomto světě existuje filosofie i nadále, ale spíše jako antikvární odkaz a v podobě dějin, ale mluvíli se o konci metafyziky, tak je tím míněna skutečnost, že filosofie již není návodem, jak žít a jak se jí nechat vést. Ve věku světonázorové ideologizace, institucionalizace, krize metafyziky a nástupu vědotechniky se pojetí vztahu teorie a praxe stalo sice čímsi nedotázaným, ale naprosto samozřejmým; praxe samotná bývá adorována s nevídanou silou. Ve světě, kde vládne pozitivní věda, jsou otázky smyslu vytěsňovány, protože klíčová jsou fakta a metody jejich zpracování.

\section{Teorie a praxe v aristotelském pojetí}

Na počátku evropských úvah o vztahu teorie a praxe lze nalézt platónský důraz na pěstování ctnosti, o níž je v dialogu Prótagoras řečeno (Platón, 1992), že není naučitelná nějakou sofistickou metodou (rozuměj pozitivní naukou), ale - jak ukazuje Sókratés - ke ctnosti (opírající se o výklad ideje dobra) lze dojít přes porozumění složitosti idejí, což znamená: nechodit se učit k sofistům, ale absolvovat náročnou cestu filosofie. Tohoto sókratovsko- 
platónského dědictví se ujal Aristotelés (1996) v etických úvahách, v nichž znovu otevřel problém formování ctnosti ${ }^{2}$ a dobrého života, $\mathrm{k}$ jehož utváření měla sloužit filosofie.

V Aristotelském konceptu jednání je pozoruhodné odlišení konkrétního cíle jednání od jeho motivů ( $\mathrm{k}$ vůli čemu), nebot' teprve v rovině odhalení důvodů je možné mluvit o svobodě volby. Člověk by v oblasti volby měl usilovat o pravou blaženost, což znamená usměrnit své jednání tak, aby žádost směřovala $\mathrm{k}$ nejvyššímu dobru a ne $\mathrm{k}$ tomu, co se $\mathrm{s}$ nejvyššími cíli v lidském životě neslučuje. Nejvyšší cíle nejsou výsledkem volby, ale jsou tím, kvůli čemu vůbec konáme. Každé lidské jednání (praxis) se projevuje ve světě, ale odehrává-li se na základě lidské volby, obsahuje motivy, principy či smysl. A tyto vnitřní komponenty jednání jsou významnější než samotná lidská aktivita. Také ctnost (areté) je posuzována zdaleka nikoliv podle toho, co jedinec koná, ale především dle účelu, k němuž směřuje. Jednání je u Aristotela provázáno s pojetím života jednajícího, který prostřednictvím aktivity směřuje k uskutečnění života a jeho cílů; volba je vázána na představu, co je dobrým životem, ale v některých stavech mysli se lidé ocitají teprve na základě svých vlastních aktivit. Soustředíme-li se na vnitřní motivaci k jednání, pak pro Aristotela bylo samozřejmostí, že počátek každého jednání se odvíjí z člověka samotného. Tím pádem je každý odpovědný za svou činnost. Veškeré jednání vyplývá z povahy lidské bytosti či z jejího charakteru, ale člověk svým vlastním jednáním spoluvytváří svou povahu, nebot' povaha není výsledkem kontemplace, ale formuje se právě v jednání. Odpovědnost za vlastní jednání znamená, že se nelze vymlouvat na neznalost (zákonů apod.), ani na opilost či nedbalost, protože je v moci každého, aby se o tyto záležitosti postaral. Volní jednání je vždy provázáno s rozumem a rozum s jednáním.

Pro úvahu o ctnostech Aristotelés užíval interpretační aparát, který převzal z platónské akademie. Výraz epistémé, užívaný pro pravé (teoretické) poznání, značí, že poznávací proces se vztahuje především k tomu, co má obecnou platnost. A to je předmětem lidské moudrosti (sofiá), která může učinit lidský život štastným. $V$ umění a v poietických vědách je třeba vzít do úvahy i výraz techné, značící umění, tvorbu či dovednost - a to od zhotovení sochy, ušití bot

V Křížově překladu je užíván výraz ctnost, který není považován za zcela štastný; za lepší bývá navrhována výtečnost apod. Ctnost je kritizována za to, že obsahuje křestanské konotace, které nelze připisovat k řeckému filosofickému pojmosloví. Na druhou stranu tento výraz užívá i řada interpretů Aristotelových textů. 
až po léčbu nemocného. Techné je pojato jako tvůrčí stav, týkající se toho, co je umělou lidskou aktivitou a zkoumáním současně. Vedle toho je uveden ještě další typ konání, které se netýká tolik tvorby věcí, ale jednání obsahujícího cíl v sobě samém - a toto jednání je označeno jako fronésis. Ta je vyložena jako „schopnost správně uvažovat o tom, co je pro něj (pro člověka - vložil jk) dobré a prospěšné, ne ovšem částečně, např́klad co je přiměřeno zdraví nebo síle, nýbrž o tom, co slouží správně vedenému životu vůbec" (Aristotelés, 1996, 1140a, s. 154). Fronésis obsahující rozumnost, uměřenost, rozvážnost, opatrnost či střídmost byla pojata jako ctnost opřená jak o hodnotovou racionalitu, tak o praktické konání, a ten, kdo tuto schopnost studuje, tak se zabývá analýzou hodnot a zvažováním důsledků, které lidské jednání může přinést. Aristotelés zcela jasně vyjádřil přesvědčení, že fronésis je podřízena moudrosti (sofiá), protože nesměřuje $\mathrm{k}$ nejobecnějšímu poznání, ale je zacílena k činnosti či konání a vztahuje se vždy k jednotlivým př́ípadům. Proto se také opírá o praktické zkušenosti.

Ohlédneme-li se na dějiny západ ního filosofování, je pozoruhodné,že epistémé i techné se udržují v evropském myšlení dodnes, zabydlely se v něm dokonce $\mathrm{v}$ celé řadě odvozených termínů, ale pojem fronésis i moudrosti (sofiá) se staly součástí možností, které si další tradice sama uzavřela tím, že položila důraz na vědeckou racionalitu, techniku, pragmatická či instrumentální řešení. ${ }^{3}$ Celé aristotelské filosofování bylo neseno touhou projasnit, ale současně organicky provázat vztahy mezi veškerými pojmy popisujícími lidský život a ukázat jak se etické principy váží nejen na představu dobrého žití, ale i na praktickou aktivitu, v níž teprve dochází k naplnění životních cílů a funkcí. A mnohá běžná konání jsou podřízena praktickým vědám, které podle Aristotela určují, co je třeba konat, čemu se naopak vyhnout. To platí do té míry, do jaké se jedinec dokáže vymanit z každodenních lidských podmínek a zájmů a nejvyšším dobrem se pro něj stane teoretické poznání, či lépe: zaměřenost na teoretické vědění. Ale konečným cílem života není teoretická distance, nebot' člověk je aktivním činitelem a spěje spolu s kultivací rozumu k dosažení dobra, což z něj činí etickou bytost. A životního naplnění tato etická bytost dojde v pěstování moudrosti a jednotlivých ctností, včetně fronésis.

3 Tímto problémem dalšího vývoje aristotelských pojmů se zabýval Flyvbjerg (1996) ve svém článku Nárys užití etiky pro trvale udržitelný rozvoj. 


\section{Teorie a praxe po obratu $\mathrm{v}$ antropologické filosofii}

Po zhroucení německého idealismu odehrávajícího se po Hegelově smrti bylo př́íznačné, že odmítnutí nejvyššího jsoucna, substance či absolutního ducha bylo nahrazeno přesvědčením, že vše, k čemu se člověk vztahuje, je jeho vlastním výtvorem; poslední výklad, k němuž lidské úsilí směřuje, je vlastní praktická lidská aktivita. Již v kritické filosofii L. Feuerbacha namísto hledání zakládajících metafyzických principů nastupuje antropologická orientace, která vytváří předehru k programu vyložit člověka jakožto bytost prakticky utvářející nejen sebe sama, ale i své bohy, dějiny a svůj vlastní svět. Tomuto radikálnímu obratu Marx (1967) vtiskl do vínku přesvědčení, že veškeré společenské, náboženské, ale i kulturní výtvory pramení z rodových a tvořivých aktivit člověka, $\mathrm{z}$ naplňování jeho potřeb ve společenském a praktickém konání. $\mathrm{K}$ tomu, zda marxismus vůbec přiřadit $\mathrm{k}$ filosofickým proudům se klonila ta část myslitelů, která byla ochotna připustit, že Marxovo filosofování lze uchopit na základě centrálního pojmu užitého k výkladu světa, kterým je výraz praxe.

Paralelní nástup historismu inspirovaný spory 19. století znamenal otřes $\mathrm{v}$ tom smyslu, že vedle antropologie se zrodil typ myšlení od počátku podlamující právě nově se formující snahy nalézt či konečně definovat metafyzickou podstatu člověka samotného. Nástup historismu prudce zrelativizoval i veškeré vědecké pokusy o přesnější popisy, nebot’ přesazení člověka do dějinného procesu záhy diskreditovalo i nejstarší západní určení lidské bytosti - a to jak pojetí člověka animal rationale, tak i imago Dei.

Snaha západního myšlení vymanit se z okovů metafyziky ve dvacátém století narazila na meze, které byly vytyčeny půdorysem novověkého filosofování, především nástupem kartesianismu s pojetím člověka jako subjektu. A celá novověká situace se od 17. století vyvíjela v zajetí myšlenkové konstrukce subjekt-objektového vztahu, s nímž se západní filosofie pomalu a nerada loučí, nebot' je obtížné překonat předpoklady, z nichž vyrostla a byla po několik století vyživována. Ale tyto skryté předpoklady stále ještě vedou myslitele jak ve filosofii, tak ve vědách určitým směrem, v němž je obtížné projasnit jak pojem člověka a světa, ale i to, co je lidskými výtvory - a to jak teorie, tak praxe. Čím větší rozpaky ve filosofii, tím spíše lze předpokládat, že badatelé $\mathrm{v}$ jednotlivých vědách o člověku budou rigidnější, určitější a budou usilovat oddělit se od základů, které je znejišttují, tedy odklonit své myšlenkové koncepty od tradičního evropského filosofování - a řešit tyto 
složité problémy technickými prostředky. Otázky lidského jednání ovšem nikdy nebyly pouhým technickým problémem, nebot' jejich řešení je odvislé od porozumění smyslu lidského bytí.

Pro současnou situaci je příznačné, že začínáme lépe rozumět některým lidským potřebám, mechanismům moci, autority, vzdělávání apod., ale zvláště pedagogickým disciplínám se vrací to, že explanativní složka pedagogické teorie směřuje $\mathrm{k}$ technickým popisům průběhu jednotlivých zkoumaných dějů a situací, normativní zaměření pak vytyčuje směrnice pro dílčí procesy, ale zdaleka nesahá až $\mathrm{k}$ otázce smyslu lidského života. Profil současného vědění je daleko více vědotechnické než metafyzické povahy. A tato situace naznačuje, že vhodným způsobem myšlení - pokud něco takého máme pěstovat - vhodného pro současnost je trvalé a opakované promýšlení celých dějin metafyziky. Pak teprve se znovu rozehraje celá ta složitá hermeneutická hra, která vedle tradic umožní odhalit mnohé neprozkoumané předpoklady, z nichž filosofie a tematizace jejích problémů od počátků vycházela.

Pokoušíme-li se v současnosti nalézt odpověd' na otázku, co je to praxe, pak hermeneutika dodává, že veškeré vědění má základ $v$ netematizovaném předvědění odvíjejícím se z nereflektované každodennosti - což znamená, že veškeré klíčové filosofické pojmy $\mathrm{v}$ nějaké podobě známe ještě dříve, než je učiníme předmětem filosofující reflexe. $V$ běžném životě odpověd' na otázku, co je praxe, přece zná každý. Jakmile však tento termín podrobíme zkoumání, ukáže se, že jde o jeden z nejmlhavějších. Ostatně jako vše, co je vázáno na lidskou aktivitu, jejíž proměnlivé podoby se zdají být velmi obtížně zachytitelné.

Bylo již naznačeno, že v marxismu se úzký vztah teorie a praxe stal jedním ze zcela bazálních, byl považován za „základní postulát“. Jakmile byla tato propozice nastolena, bylo příznačné, že se vytratila z jeviště světa filosofická otázka, která by vedla k úvahám o jejich provázanosti. Kosík (1965) upozornil, že pojem praxe se vyvíjel a tím pádem se proměňovala i podoba jednoty teorie a praxe. Uváděl, že praxe byla zprvu vyložena jako „sociálnost“, což znamenalo prvotní transformaci do učení o „sociálnosti člověka“. Posléze se stala „pouhou kategorií“ a korelátem poznání jako jeden ze základních pojmů teorie poznání - epistemologie. $\mathrm{V}$ další variantě se stala rovnocennou technice „a byla pochopena a praktikována jako manipulace, technika jednání, umění disponovat lidmi a věcmi, krátce jako moc a umění manipulace s věcným a lidským materiálem“ (Kosík, 1965, s. 151). A autor k tomu dodal: 
„S modifikacemi v chápání a praktikování praxe se příslušně měnily koncepce, úloha a smysl filosofie stejně jako pojetí člověka, světa a pravdy." (Kosík, 1965, s. 151). Je třeba upozornit, že zvláště třetí proměně Kosík připsal dalekosáhlé důsledky, nebot' změny v pojetí praxe směrem k manipulaci podle něj měnily podoby filosofie, člověka, světa, ale i základů teorie poznání. Kosík postřehl důležitost vlivu tématu praxe na celé myšlení v marxismu, ale již nedodal, že mnohé z toho, co uváděl, se nakonec odehrávalo spíše v živelné praktické variantě než v kritické a důsledně reflektované teoretické rovině.

Lze dodat, že vzývání praxe postupně vedlo k její fetišizaci a k pojetí, které bylo jak mimo kritiku, tak i jakoukoliv diskusi. Přitom lidská praxe je specifickým druhem činnosti odlišné od aktivity ostatních přírodních bytostí či pohybu přírody jako takové. Člověk vytváří svou svébytnou předmětnou skutečnost, která se stává jeho vlastní lidskou skutečností. Na druhé straně je třeba brát v úvahu to, že pojetí a hodnocení praxe není něčím, co má jednající bytost bezprostředně k dispozici, protože jako společenská bytost je závislá na mínění současníků a následovníků. Již Hegel (1960) věnoval problematice nezamýšlených důsledků lidského jednání jednu z kapitol Fenomenologie ducha, v níž ukazoval, jak se každý výsledek praktické aktivity v podobě hodnoceného díla vymyká jedinci $\mathrm{z}$ rukou, protože propadá soudům současníků a poté následujících generací. Na druhou stranu západní filosofie akceptovala myšlenku, že člověk je spolutvůrcem sebe sama a svých dějin a není jen bytostí teoretické kontemplace, ale zasahuje do světa a tvůrčím způsobem mění jeho podobu.

Praxe a praktická aktivita byla u mladohegelovců a jejich následovníků pojata také jako práce. A právě u té lze zdưraznit, že nejde o libovolný pohyb či činnost, ale o vědomou aktivitu směřující ke změně předmětu, k němuž je orientováno lidské konání. Takovým předmětem se mủže stát nejen výrobek, ale i dítě či dospívající, který se stal součástí výchovně-vzdělávací aktivity a je proměňován ve vzdělaného či vychovaného tvora. Pak je zřejmé, že práce se stává praktickou aktivitou, směřující k uskutečnění či naplnění předem pojatého záměru. A tento záměr je uskutečněn v předmětech mimo člověka, což v oblasti výchovy znamená i to, co by nemělo zůstat nepovšimnuto, že žák - byt' jde o jedinečnou lidskou bytost - se stává právě takovým objektem působení, k němuž směřuje účelná aktivita vychovatele tak, aby bylo dosaženo cílového stavu, postmoderně řečeno: aby došlo $\mathrm{k}$ rozvoji specifických schopností či kompetencí vychovávaného. Dosažení konečného cíle je vázáno 
na vizi, plán či představu, kterou má vychovatel po celou dobu pedagogického působení před sebou, proto výchovná práce není jen aktivita vázaná na objekt působení, ale i na vnitřní představy, cíle, vize, iluze, ale i hodnoty, z nichž byl vytvořen záměr vychovatele. Cíl není ve výchově nikdy zcela libovolný, ale pokud nejde o svévolnou manipulaci, vedou aktivity vychovatele k dovršení vnitřních možností toho, kdo je vychováván. To je nakonec to, o čem hovořil i pragmatik John Dewey, který podtrhnul, že výchova má podporovat růst, tedy rozvíjet především vlastní dispozice vychovávaného.

Myšlenka, k níž postupně dospěly moderní analýzy výrobního procesu, totiž, že mnohé výsledky nejsou viditelné, kontrolovatelné a uchopitelné - to je vychovatelům známo odedávna. Výchova je vždy poznamenána tím, že její výsledky nejsou bezprostředně dostupné a nahlédnutelné. Vychovatel žije $\mathrm{v}$ neustálé nejistotě, kolik $\mathrm{z}$ toho, co si předsevzal, a $\mathrm{z}$ toho, co od něj očekává společnost, naplnil svou aktivitou, protože celé jeho působení je závislé na interakci s živými bytostmi. A toto vzájemné působení v sobě vždy ponese něco technicky neobstaravatelného, nepropočitatelného a obtížně naplánovatelného. ${ }^{4} \mathrm{~A}$ právě o tento moment se opírají úvahy o moci a bezmoci vychovatele jako o jednom z paradoxů učitelské profese. Problematičnost výchovného působení navíc prohlubuje to, že hlavním nástrojem působení na žáky je on sám, jeho tělesnost, gesta, způsob mluvy, věrohodnost a kvalita jeho celoživotní kultivace.

\section{Problematika pedagogických praxí v přípravě budoucích učitelů}

Pedagogika od svých počátků až po dnešní dny osciluje mezi filosofující teorií a pozitivisticky a empiricky laděnou vědou. Pod teorií myslíme převážně vědu jakožto systém uspořádaných výroků, poznatků či fakt. Z tohoto hlediska je pedagogická teorie otevřenou záležitostí, ale vztah teorie a praxe je artikulovatelný jen $\mathrm{v}$ teoretické rovině, $\mathrm{v}$ praxi jej lze pouze naplnit. Tento vztah lze tematizovat $\mathrm{v}$ celé řadě rovin: (a) jako vztah teoretických a prakticky orientovaných předmětů (výcviky, tréninkové aktivity apod.) včetně absolvování pedagogické praxe $\mathrm{v}$ průběhu studia, (b) $\mathrm{v}$ obecné rovině jako přípravu na budoucí celoživotní praktickou aktivitu - na řízení

4 Mnohé zkušenosti např́iklad ukazují, že celá řada tzv. praxí zařazených do programů výuky již na středních školách je ve skutečnosti vysoce kontraproduktivní v tom, že mnohé adepty obory definitivně odradí od touhy se studovanému oboru po absolvování školy věnovat. 
vyučovacího procesu. V nejširším pojetí by bylo možné zvažovat přípravu na celoživotní vzdělávání a na postupné proměny praktických aktivit v průběhu životní dráhy apod. Pojetí praxí je však ve vědním profilu pedagogiky pojato jako zcela technická záležitost, jejíž filosofické konotace nebývají tématem reflexe tak, jak jsme tomu byli svědky v aristotelismu a jeho repríze v novohegeliánství přivádějícím na filosofickou scénu novou verzi některých aristotelských motivů.

Systém tzv. pedagogických praxí představuje jeden z klíčových problémů fakult připravujících budoucí učitele a je předmětem cyklicky ožívajících diskusí již přes půl století. Část tradičních fakult (filosofická, přírodovědecká, matematicko-fyzikální, chemicko-technologická, zemědělská a další) připravujících především středoškolské učitele klade důraz v první řadě na teoretickou přípravu a praxe bývá pojímána spíše jako doplněk a završení teoretické přípravy. Na těchto fakultách se traduje teze, že nejpraktičtější je dobrá teorie. Tato floskule maskuje nechut' radikálněji inovovat stávající systém praxí. Mnohé pedagogické fakulty s daleko větším rozsahem záběru, nebot' zpravidla připravují učitele od základního stupně až po střední školy, kladou výrazný akcent na praxi, pokoušejí se vyhovět jak požadavkům studentů těchto fakult, tak tlaku budoucích zaměstnavatelů. V současném rostoucím přetížení vysokoškolských učitelů plynoucím nejen z nutnosti zajistit vlastní výzkum a publikační aktivity, ale i vyplňovat množství dat do elektronických systémů školy, podávat řady nejrůznějších hlášení, vyplňovat formuláře grantových úkolů, podklady pro akreditace oboru a mnohé další neproduktivní aktivity, dochází k tomu, že vyučující obecných disciplín, včetně vyučujících oborových didaktik mohou být zcela odtrženi od toho, co se vlastně odehrává v průběhu praxí, protože o ty pečují pouze vybraní zaměstnanci kateder či dokonce fakult.

Důrazy na teorii či naopak na praktickou přípravu mají své silné a slabé stránky, ale obecně se dá říci, že mnohé konstatované nedostatky jsou dány především tím, že současná příprava budoucích učitelů je výsledkem celé řady politických kompromisů po listopadu 1989, kdy bylo dosaženo jakéhosi př́pravného minima, které je odlišné od zvyklostí v celé řadě zemí, v nichž jsou budoucí učitelé připravováni na vysokých školách. Dále je zcela nerealistické očekávat, že studium včetně systému praxí umožní budoucímu učiteli opustit fakultu tak, jak kdysi z Diovy lebky vyskočila Palas Athéna v plné zbroji. Připomeňme, že budoucího učitele se tradičně ujímala škola, 
do níž nastoupil jako zaměstnanec a v systému uvádění začínajícího učitele jej postupně nejméně jeden rok zkušenější kolegové zasvěcovali do celé řady praktických aktivit. Na rozdíl od řady jiných zemí schází u nás další systém atestací, přezkoušení apod. poté, co je nástupní zácvik realizován. Filosoficky situaci zasvěcení do učitelské profese výstižně popsal Michálek (1995) v Topologii výchovy, v níž ukazuje, že matka se nestává matkou porodem dítěte, ale každodenním stykem s ním, kdy se postupně naučí, co to vlastně znamená být v trvalé interakci s dítětem každý den. A podobně se učitel stává učitelem tváří v tvář žákům, protože teprve od nich se ve vzájemné interakci naučí to, co vlastně tato profese obnáší.

Důvodem organizace pedagogických praxí bývá, aby studenti dokázali vhodnými vyučovacími metodami a promyšlenou organizací vyučovacího procesu formovat u žáků nabyté znalosti, vědomosti a dovednosti. I když se často objevovaly stížnosti studentů na nedostatečnou praxi, mnozí odborníci jsou přesvědčeni, že základ problémů leží v nedostatečně propracované teorii jak obecné, tak speciálních didaktik - a tím pádem i v nereflektovaných problémech teoretické i praktické povahy.

Principiálně existuje shoda $v$ tom, že úroveň praxí je částečně odvozena od zázemí, které bylo vytvořeno na fakultních školách. Otázkou je rovněž to, do jaké míry je ještě živou a účelnou komunikace fakult se školami, na nichž je praxe realizována. A zcela specifickou kapitolou jsou nedořešené otázky praxí $v$ kombinovaném studiu. Je také možné se ptát, do jaké míry se fakultám daří zajistit praxi na všech typech škol, pro které absolventi fakult získávají aprobaci. Palčivý je problém, jaké typy odborných škol a učilišt' se podaří zajistit pro praxi na středoškolských institucích, kterými - jak známo - nejsou pouze gymnázia.

Podceňovanou skutečností př́pravy budoucích učitelů bývá výuka aprobačních předmětů tvořících základ či těžiště přípravy na učitelství. Ještě více zanedbávaná je oblast př́pravy na řešení výchovných problémů, což se již v průběhu praxí projevuje v bázni či dokonce strachu ze zvládání každodenních výchovných problémů s kázní žáků, s jejich pozorností či motivací. Někdy bývá poukazováno na to, že mezi teorií a praktickými výstupy leží nevyužívaný mezičlánek - a tím jsou cvičení, která by mohla tvořit vhodný přechod od přednášek a seminářů k rozvoji pedagogických dovedností. Takovým vhodným cvičením by mohlo být i tzv. mikroučení, založené na podrobné analýze videozáznamů kratších výstupů, věnovaných 
dílčím tématům, jako je zahájení hodiny, výklad, přezkušování látky, organizace některých vyučovacích forem, využití didaktické techniky apod.

Jedním z předpokladů úspěšně fungujícího systému praxí je vytvoření propracovaných oborových didaktik, což je úkol, který je na řadě oborů trvale podhodnocován. Nejde jen o nedostatek textů a inovací v těchto disciplínách, ale často je na oborové didaktiky pohlíženo jako na ty vyučující, kteří se věnují didaktickým otázkám, protože nejsou špičkovými odborníky oboru. Díky těmto předsudkům se pak situace točí v kruhu, protože pro pěstování těchto oborů se obtížně hledají erudovaní odborníci, kteří by do této oblasti byli schopni přinášet nový teoretický nadhled a realizovat v ní vlastní vědecký výzkum.

Důležitou součástí úspěšné praktické př́ípravy je její rozvržení a realizace, tedy to, jak jsou uspořádány široké možnosti praxí - počínaje nahlížením na problémy pedagogického provozu až po aplikace teoretických poznatků při diagnostice problémových situací a po jejich samostatné zvládání. Je evidentní, že praxe vytváří bázi pro budoucí profesionální činnost, utváří postoje studujících a kultivuje jejich pedagogické dovednosti, ale ovlivňuje i celou jejich osobnost. Má tedy výrazný vliv na formování absolventů učitelského studia.

Za neobyčejně důležitou součást přípravy budoucích učitelů jsou považovány hospitace, které tvoří první uvádějící krok do života školy. V průběhu hospitací (či tzv. náslechů) se ze studentů stávají badatelé, jejichž aktivita má smysl, pokud jsou dostatečně připraveni na to, co bude předmětem jejich vědeckého pozorování. Hospitace nemají být nikdy pouhým nestrukturovaným a nepřipraveným zíráním, ale mají mít předem jasně definované cíle, má být určeno místo, hodina a den hospitace v určeném předmětu, má být stanoveno, jaké dimenze výukového procesu či jednotlivých situací budou předmětem pozorování a jaké typy záznamů si studující o pozorování povede. Za vhodné lze považovat i to, aby hospitující znal předem probírané téma hodiny, charakteristiky dané tř́́dy a měl možnost se seznámit s přípravou učitele na vedení náslechové hodiny. Pouhé nahlížení či nazírání na jevy vůbec nezaručuje možnost porozumět pozorovaným jevům. ${ }^{5}$ Proto se významnými stávají způsoby záznamů a popisu sledovaných procesů a parametrů

\footnotetext{
Autorem této stati před lety hluboce otřáslo, když na otázku, co vlastně budou studenti na tzv. úvodních hospitacích konat, odpověděl jeden pracovník z oddělení praxí bez jakéhokoliv zaváhání, že budou pozorovat pedagogické kategorie.
} 
vyučovacích situací, nebot' předem sestavené pozorovací archy či formuláře, s jejichž pomocí studující zachycuje sledované jevy, jsou vhodnou pomůckou k základní orientaci. Zvláště sociální psychologie ukazuje, že každé pozorování je výběrové a závisí na apercepci, tedy na předem vytvořených schématech zkoumaných jevů, protože každé vnímání má výběrový charakter. Platí, že pokud hospitující nepronikl k podstatě vyučovacího procesu, potom nebude schopen $v$ průběhu hospitace zahlédnout žádné významnější či dokonce podstatné problémy. Student by měl rozumět tomu, proč učitel změnil strategii či metodu, proč zvýšil hlas či proč určitým způsobem oslovil žáka. Měl by rozeznat, zda jej žák popudil, nebo se jej vyučující snažil podnítit k vyššímu výkonu.

V diskusích kolem hospitací zkušení vyučující upozorňují na skutečnost, že jen obtížně lze vyhovět požadavku na větší časovou dotaci pedagogické praxe, proto reálnou se jeví pouze cesta ke zvýšení její účinnosti. Smyslem hospitací se většinou rozumí kultivace schopnosti proniknout od jevové stránky vyučovacího procesu až k jeho podstatě. Náslechy umožňují (a) seznámit se s možnostmi řízeníškolní práce formou pozorování, náhledů či inspekcí,(b)jde o prostředek tzv. pedagogické diagnostiky umožňující zaujmout i reflektivní a kritický postoj nejen k práci učitelů, ale i ke své vlastní, (c) jde o prostředek získávání širokého spektra zkušeností u hospitujících. Při dobře zvládnutých násleších by se v závěrech a vyhodnocení sledované hodiny měly hospitující vyhnout sdělování pouhých dojmů, tedy frázím odvolávajícím se na to, co si student „myslí“, co „cítil“ nebo co konstruuje jako hypotézy. Skutečné poznání směřuje k odhalování toho, co je jádrem a nutnými součástmi vyučovacích postupů, které mají vždy dva souběžné děje: (a) předávání odborných znalostí a (b) regulaci sociálních vztahů ve třídě. Při analýze záznamů z hospitací je vhodné věnovat pozornost tomu, zda protokol z vyučovací hodiny obsahuje strohý popis jejího průběhu, či v něm lze nalézt i pasáže obsahující kritické rozbory a připomínky $\mathrm{k}$ pozorovaným procesům.

Při koncipování systému praxí bývají odlišovány receptivní fáze (zaměřené na zachycení a analýzu problémů) a aktivní fáze, v nichž: (a) studenti procházejí prvními pokusy a napodobují postupy odpozorované v průběhu hospitací, (b) se odehrává samostatné zvládání větších celků učiva. Již před prvními aktivními výstupy se doporučuje vést $\mathrm{v}$ př́pravě studující k tomu, aby se co nejdříve odpoutávali od soustředění na svůj vlastní výkon a zvládnutí vyučovací hodiny a naučili se vnímat a myslet především na ty, 
kteří jsou předmětem jejich působení - tedy na žáky, na jejich vlastnosti a na kompetence, které u nich mají rozvíjet.

Za varující by měla být považována zkušenost z vyhodnocování praxí, poukazující na skutečnost, že převážná většina studentů bývá obvykle spokojena s úrovní vlastního vystoupení před žáky. Protože většinou nejsou dostatečně připraveni na vlastní osobní rozvoj, pojímají připomínky či výhrady k některým činnostem jako připomínky k průběhu praxe, která se jim pak jeví jako nedostatečně připravená a zajištěná. Místo toho, aby se naučili reflektovat své vlastní aktivity a pojímali podněty a připomínky z okolí jako obohacující, mají poměrně výraznou tendenci vinit fakultu z nedostatečné př́pravy na kontaktní výuku se žáky. Evidentní je ve skutečnosti spíše nedostatečně rozvinutá schopnost nalézt zdroje chybných či nedostatečných výkonů v sobě samém; typická bývá i nedostatečně kultivovaná schopnost odhalit a kriticky nahlédnout vlastní slabé momenty či chybné výkony vůbec. Mnozí touží především po tom, aby okolí přesvědčili, že jsou již více či méně kompetentními učiteli a jsou spokojeni v okamžiku, kdy se k nim žáci jako $\mathrm{k}$ učitelům disponujícím jistou mírou autority začnou stavět a chovat.

Zcela jistě není na místě př́lišná hyperkritičnost $\mathrm{k}$ výkonům začínajících učitelů, ale základním pravidlem profesionálně vedené výuky je, že žák není a za žádných okolností by neměl být pokusným králíkem. Proto je třeba, aby i začínající učitel vystupoval na určité standardní odborné úrovni, která nebude pro žáky ohrožující či dokonce poškozující. Lze říci, že snaha dojít k určitému vlastnímu uspokojení u praktikujících studentů je nejen lidská, ale i psychologicky pochopitelná, ale současně je vhodné ukázat, že mistrovství se dosahuje dlouhodobým a postupným zlepšováním vlastní aktivity.

Specifickou kapitolou vlastní pedagogické praxe je př́prava na práci s moderní didaktickou technikou a tvorba vlastních vyučovacích materiálů či pomůcek. Dnešní škole je vytýkáno, že přes ztrátu monopolu na vzdělání, který měla ještě na konci 19. století, by bylo vhodné do výuky zapojit i znalosti a dovednosti žáků, které získali mimo vyučování; tedy při práci s počítači, při sledování televize, internetu, při práci s celou řadou dalších elektronických médií a programů. Snaha separovat školu od života je tradiční výtkou našim školám a začínající učitel by se měl umět s touto situací vhodně vypořádat, v lepším př́ípadě ji využít k obohacení průběhu vyučovací hodiny. 


\section{Pár slov závěrem}

Na počátku této úvahy jsou uvedeny poznámky směřující $\mathrm{k}$ upozornění, že vztah teorie a praxe není dosud jasně definován. Přestože byl v minulosti vícekrát tematizován a činěn i téměř kultovním, neznamená to, že tyto vztahy lze dnes technicky popsat a projasnit. A to i přesto, že jde o fascinující vazby, jejichž kultivace si vyžaduje jak důkladné promýšlení a posuny $\mathrm{v}$ teorii studovaného oboru, tak v psychologii žáků, v kultivaci schopnosti supervize vlastní aktivity vyučujícího a v propracování jak obecně didaktické problematiky, tak oborových didaktik. Na druhou stranu stojí před fakultami připravujícími budoucí učitele trvalý úkol zvládnout přípravu, organizačnětechnické, ale i personální zajištění praxí na dobře vybraných cvičných školách, ale i propracování systému vyhodnocení a kritického zpracování praktických aktivit.

Je zřejmé, že mnohé nastíněné problémy si nakonec vyžádají technické zásahy do organizace vysokých škol - od nového uspořádání vzdělávacích plánů až po organizaci a zajištění praxí. Ve skutečnosti jádro řešení vztahu teorie a praxe leží i mimo vědotechniku a nelze jej zvládnout sebelépe míněnými administrativními zásahy, ale kvalitativní změny odvisí v první řadě od celkové kultivace a péče o duši budoucích učitelů, což je problém, který vyžaduje spíše intervenci filosofie a zvýšení kvality vzdělávacího procesu na vysokých školách. Při současném uspěchaném a k povrchnosti spějícímu systému vysokoškolského studia lze nějaké hlubší změny očekávat jen stěží. Ale problém není jen $\mathrm{v}$ rámcích, $\mathrm{v}$ nichž se př́íprava budoucích učitelů odehrává. Dobrá teorie bez praxe je př́liš akademickou a odtrženou od života, podobně jako pouhá praxe př́liš mnoho poučení nepřinese. 0 vztahu teorie a praxe lze říci, že praxe bez teorie je slepá, naopak teorii bez praxe zvláště v oblasti umění učit hrozí, že se stane jen soustavou prázdných pojmů či bezobsažných teoretických konstruktů. Budoucím adeptům učitelství je také třeba neustále připomínat, že - jak uváděl již Aristotelés - nesou plnou odpovědnost za kvalitu své vlastní vysokoškolské průpravy i celoživotní kultivace, odvíjející se z praktického jednání, které konec konců bude formovat i jejich charakter. I v době vlády vědotechniky právě pedagogická aktivita v sobě vždy bude obsahovat otázky smyslu, které nejsou řešitelné technickými prostředky, ale lze se k nim přiblížit pěstováním moudrosti a filosofickou kultivací. 


\section{Literatura}

Aristotelés (1996). Etika Nikomachova. (překlad Antonín Kř́íž, 2. vydání). Praha: Rezek.

Aristotelés (2003). Metafyzika. (překlad Antonín Kříž, úprava Petr Rezek; 2. vydání). Praha: Rezek.

Flyvbjerg, B. (1996). Nárys užití etiky pro trvale udržitelný rozvoj. Aristotelés, Foucault a progresivní fronésis. Filosofický časopis, 44(1), 101-122.

Hegel, G. W. F. (1960). Fenomenologie ducha. (překlad Jan Patočka). Praha: nakladatelství ČSAV.

Kosík, K. (1965). Dialektika konkrétního (studie o problematice člověka a světa). Praha: nakladatelství ČSAV.

Marx, K. (1967). Odcizení a emancipace člověka. Praha: Mladá fronta.

Michálek, J. (1995). Topologie výchovy (Místo výchovy v životě člověka). Praha: Oikoymenh.

Platón (1992). Protágoras. (překlad František Novotný; 2. vydání, edice Oikoymenh) Praha: Institut pro středoevropskou kulturu a politiku.

Synek, S. (2011). Lidská přirozenostjako úkol člověka. Filosofická interpretace Etiky Nikomachovy. Praha: Togga.

\section{Autor}

Doc. PhDr. Jaroslav Kota, Univerzita Karlova, Filozofická fakulta, Katedra pedagogiky, Celetná 20, Praha 1, 110 00, e-mail: jaroslav.kota@cuni.cz

\section{Treatise on selected problems of theory and practice in the area of educational sciences}

Abstract: This treatise mentions the relationship between theory and practice in ancient and modern times and points to the present fetishization of practice. It also refers to the change of philosophising and draws attention to the arrival of sciencetechnology, which has taken over the present society. The question of the relationship between theory and practice is discussed from a number of viewpoints; the differences in emphases placed on the value of theory and practice are highlighted. The problem of practice schools (i.e. schools used for teacher training) is mentioned, as well as the problem of microteaching, observations, teacher students' own performances and selected aspects of the relationship to extra-curricular activities that a teacher should be able to make use of.

Keywords: episteme, philosophy, phronesis, observation, marxism, microteaching, theory, practice, present times, sapience, techne, science-technology 